\title{
Horizontal Integration with Emphasize on IoT: from Tropical Functional Food Research to Teaching Excellence
}

\author{
https://doi.org/10.3991/ijim.v14i12.15581 \\ Anton Rahmadi $\left.{ }^{(}\right)$, Miftakhur Rohmah, Uni Wahyuni Sagena \\ University of Mulawarman, Samarinda, Indonesia \\ arahmadi@unmul.ac.id
}

\begin{abstract}
The laboratory is a research powerhouse being a transportation membrane to propagate new and proven knowledge. This paper aims to descriptively disseminate the concept of horizontal integration with emphasize on Internet of Things (IoT) from research in tropical functional food resources to teaching excellence framework. The five-stage framework includes (1) vision internalization, (2) persistence propagation, (3) new technology adaptation, (4) extending collaboration, and (5) outcome integration. The vision internalization stage produces a better understanding of the big picture and systematic approach. The experience is then brought to Research Methodology and Research Design classes. Persistence propagation may be better translated to relentlessly solving the problem and to increase the laboratory power, including providing fail-safe and verification procedures of possibly dubious results produced in the laboratory. The research may improve operating procedures or methods in a laboratory manual. The movement of open hardware dan IoTmakes it possible for faster technology adaptation to food-laboratory. IoT is integrated into the closest courses. When an integration requires expansion and collaboration, students are prepared to conduct functional food research in partner laboratories. The outcome integration fully materialized when enough new and related knowledge are accumulated. Researchers may visit and align the current curriculum in the subject of Functional Food Technology. In summary, the horizontal integration with emphasize on IoT results in a unique set of research-teaching excellence framework that is incrementally developed.
\end{abstract}

Keywords-Research-teaching integration, technology adaptation

\section{Introduction}

Science may start from observing and therefore accepting empirical evidence. Transferring knowledge in hard science often requires a unique conceptual model that is better suited to specific targets. Transdisciplinary is preferable due to the vast, diverse nature of science, technology, engineering, and math (STEM) fields [1]. For example, a study on functional food is multi-disciplinary related to the biological nature of plants, biochemical pathways of active compound synthesis and functions in 
human or animal model, physical and engineering properties of designated food material, and preference in sensory delivery. Thus, translating research results into teaching excellence has to be delivered in stages. Based on our team research-teaching experience for the past seven years, we proposed the concept of research translation to teaching in five-stage framework. The framework includes (1) vision internalization, (2) persistence propagation, (3) new technology adaptation, (4) extending collaboration, and (5) outcome integration.

Hovarth et al. [2] suggested no straightforward method of delivering scientific findings to classes. Therefore it is called an art of teaching excellence. In the field of technology, showing by way of trial and error is an option due to feedbacks received in both erroneous and successful conditions that are intended to increase the experience of the students. At least, four consensuses of from research to teaching framework are accepted, consolidate information, correlate learning principles, developing learning strategies, and finding causal mechanism. These consensuses corroborate our experience in research-teaching experience, especially in the framework of vision internalization and persistence propagation.

During the guest lecture in August 2019, Professor Kinuyoshi Shimizu from Kyushu University said that finding and knowledge in functional food and herbal medicine are often based on verification of folklore and myth. The past information or local wisdom, in many cases, is to be proven by an acceptable empirical approach. In resemblance of this statement, Tu [3] stated that extensive research in artemisinin was started from Traditional Chinese Medicine knowledge. Artemisinin is a class of sesquiterpene lactones isolated from Artemisia апnиа. Professor Tu Youyou received the 2015 Nobel Prize in Medicine for deriving artemisinin to cure malaria. The two experts have shown new technology adaptation, extending collaboration and outcome integration concepts.

Comprehension is highlighted to have important implications in translating knowledge to understanding [4]. Causal relationship is better taught in re-search processes and lead to the generation of inferences in the specific topic of teaching. In this case, verification and repeated laboratory experiments, i.e., measurement of antioxidant activity in a specific functional food, is important to produce the required skill and also to verify possible errors in the testing schemes. This is aligned with the framework of persistence propagation and outcome integration.

This paper aims to descriptively disseminate the concept of horizontal integration with emphasize on IoT from research in tropical functional food resources to teaching excellence based on five-stage framework of (1) vision internalization, (2) persistence propagation, (3) new technology adaptation, (4) extending collaboration, and (5) outcome integration. 


\section{$2 \quad$ Material and Method}

\subsection{Data collection and data analysis}

The experience of teaching was first handily reported. Secondary data were collected from the Academic Information System of the University of Mulawarman from 2015 to 2018. Datasets were arranged in a yearly manner, and percentages of data were calculated based on the total number in the respective year. Assumptions, models, and analysis were carefully developed upon secondary data and teaching experience from 2005-2019.

\section{Result and Discussion}

\subsection{Student input challenge}

We have conveyed the challenges faced by teachers in the interior of Kalimantan to develop human resources at the level of secondary school students [5]. Graduates from High School or Vocational (SMA/K) are the raw material for students in tertiary education institutions in Kalimantan. For example, the National Examination has never been carried out ideally in the interior of Kalimantan. The reasons are the scarce extended reading material, unequal teacher-student ratios, teacher qualifications, substandard learning facilities, and environmental conditions that force both teachers and students to study in improvised conditions.

The slogan that is often heard about the problems of students' raw materials in Kalimantan may be summarized in three sentences, namely: (1) smart and rich children go to school abroad, (2) bright but less rich children go to school in Java, and (3) children who have not honed their intelligence at the same time are economically less fortunate then attending school at the university in Kalimantan. Tables 1 and 2 may provide a current situation in the Agricultural Faculty of our university. Even though it may be debatable, the issue of the quality of raw materials for these students has been made several times as one of the challenges in preparing the analysis in the Strategic Planning document in several work units within the university environment in Kalimantan [6] (unpublished work).

Language is another big challenge (see Figure 1). Students that are coming from the interior of Kalimantan may not have proper exposure to a foreign language, i.e., English, since the supply of English teacher is scarce. Therefore, learning English as a third language, the second is their tribal language, is a luxury to new students from the remote area [5]. Four years of university education are spent with a great effort to learn a foreign language at an accelerated pace. 
Table 1. Percentage of student based on tuition fee segregation

\begin{tabular}{|c|c|c|c|c|c|c|}
\hline $\begin{array}{c}\text { Year of } \\
\text { Intake }\end{array}$ & $\begin{array}{c}\text { Govt } \\
\text { subsidi-zed }\end{array}$ & $\begin{array}{c}\text { Subsidized (cat } \\
\text { 1) }\end{array}$ & $\begin{array}{c}\text { Subsidized (cat } \\
\text { 2) }\end{array}$ & $\begin{array}{c}\text { Break-even } \\
\text { (cat 3) }\end{array}$ & $\begin{array}{c}\text { Cross- } \\
\text { subsidzing (cat } \\
\text { 4) }\end{array}$ & $\begin{array}{c}\text { Cross- } \\
\text { subsidizing } \\
\text { (cat 5) }\end{array}$ \\
\hline 2015 & 1,14 & 2,27 & 22,16 & 62,50 & 9,09 & 2,84 \\
\hline 2016 & 26,95 & 4,30 & 11,33 & 15,63 & 32,81 & 8,98 \\
\hline 2017 & 1,00 & 2,68 & 8,03 & 27,76 & 39,80 & 20,74 \\
\hline 2018 & 15,72 & 0,31 & 5,03 & 25,16 & 31,13 & 22,64 \\
\hline
\end{tabular}

Table 2. Percentage of student origin 2016-2018

\begin{tabular}{|l|c|c|c|c|c|c|c|}
\hline \multirow{2}{*}{ Year } & \multicolumn{7}{|c|}{ Percentage of the background of the student } \\
\cline { 2 - 8 } & $\begin{array}{c}\text { East } \\
\text { Kaliman- } \\
\text { tan }\end{array}$ & $\begin{array}{c}\text { Other } \\
\text { Kaliman- } \\
\text { tan }\end{array}$ & Sulawesi & Sumatera & Java & Others & Overseas \\
\hline 2016 & 94,38 & 0,30 & 0,55 & 2,16 & 1,30 & 1,25 & 0,05 \\
\hline 2017 & 89,15 & 0,38 & 0,59 & 2,31 & 1,29 & 6,23 & 0,05 \\
\hline 2018 & 87,66 & 0,34 & 1,26 & 2,34 & 1,54 & 6,74 & 0,11 \\
\hline
\end{tabular}

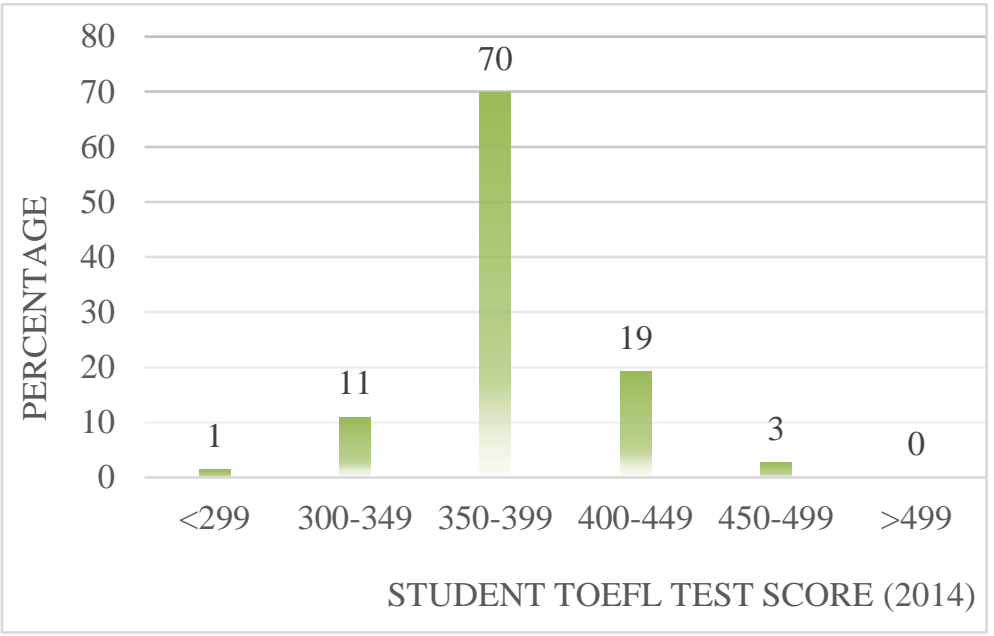

Fig. 1. TOEFL test score of student

\subsection{Student skill and knowledge gap identification}

A psycho-analytical and cultural orientation is used to identify gaps in student raw materials. In this orientation, the understanding of the tendency of individual mindsets in efforts to transform students [7]. The transformation approach of students must touch the four sides of psycho-analysis orientation from students, namely (1) acceptance of things that are logical, quantified and factual, (2) acceptance of accepting views that are comprehensive, complete, and the reasons behind giving a job/task, (3) acceptance of interpersonal and exemplary closeness, and (4) acceptance of gradual 
and organized development steps. Meanwhile, based on cultural orientation, the approach taken to local students is in three aspects, namely thought patterns, patterns of identification and personal motivation, and patterns of interaction. These three aspects of cultural orientation determine the step of transformation that will be undertaken for students from the interior of Kalimantan [8].

Table 3. Student Skill and Knowledge Gap Identification

\begin{tabular}{|l|l|l|}
\hline \multicolumn{1}{|c|}{ Aspect } & \multicolumn{1}{|c|}{ Early Stage Condition } & \multicolumn{1}{c|}{ Final Intended Condition } \\
\hline $\begin{array}{l}\text { Knowledge } \\
\text { Discovery }\end{array}$ & $\begin{array}{l}\text { Awaiting input or ideas from the lecturer } \\
\text { or supervisor }\end{array}$ & Able to seek and express ideas/opinions \\
\hline $\begin{array}{l}\text { New Idea } \\
\text { Exploration }\end{array}$ & $\begin{array}{l}\text { Do not dare to reveal differences in } \\
\text { views or ideas }\end{array}$ & $\begin{array}{l}\text { Understand that different views or ideas can be } \\
\text { a novelty }\end{array}$ \\
\hline $\begin{array}{l}\text { Thinking } \\
\text { Assessment }\end{array}$ & $\begin{array}{l}\text { Mental condition for something: if it's } \\
\text { not right, it must be wrong }\end{array}$ & $\begin{array}{l}\text { Psychological conditions that understand the } \\
\text { existence of alternative opinions that both may } \\
\text { be true }\end{array}$ \\
\hline Fact-Finding & $\begin{array}{l}\text { Not able to distinguish between claims } \\
\text { supported by facts or not }\end{array}$ & $\begin{array}{l}\text { Being able to differentiate between claims } \\
\text { supported by facts or not, and not exaggerating } \\
\text { a claim. }\end{array}$ \\
\hline Delivering Ideas & $\begin{array}{l}\text { Focusing on one thing and is repetitive } \\
\text { with a flow that rotates in one idea }\end{array}$ & $\begin{array}{l}\text { Being able to express opinions with a flowing } \\
\text { stream and with a good transition between } \\
\text { ideas }\end{array}$ \\
\hline Confidence & $\begin{array}{l}\text { Easily influenced by the views of } \\
\text { groups/friends regardless of the facts }\end{array}$ & $\begin{array}{l}\text { Having a steady view and understanding of } \\
\text { interdependencies based on a review of existing } \\
\text { facts }\end{array}$ \\
\hline Integrity & $\begin{array}{l}\text { Focusing on the outcome or final value } \\
\text { of a work }\end{array}$ & $\begin{array}{l}\text { Focusing on the process of achieving the results } \\
\text { of a work }\end{array}$ \\
\hline
\end{tabular}

The origin of students may not the leading cause of inferiority [9]. In some ways, they are like diamonds that have not been honed. Some national competitions were won by students from non-favorite schools located in the remote area. A local student from Kembang Janggut Subdistrict, another remote area in Kutai Kartanegara Regency, together with two colleagues, managed to become a national finalist in the 2017 Food Innovation Competition. Two students from North Paser and Bunyu Island were able to participate in an internship program at the Tea and Quinine Research Center, West Java. They then participated in a joint research program at Gadjah Mada University, Yogyakarta. From this example, the transformation of student abilities in the context of the required skills mentioned in Table 3 becomes crucial.

\subsection{Student orientation development strategy}

The grouping of students' interests and talents needs to be identified to empower students according to their potential (see Figure 2). This grouping will support the internalization of vision and development of persistence, especially for students who are interested in specific fields, such as research, organization, art, traveling, and language. Passion will grow if students develop according to their interests and talents [10]. 
For example, with this student orientation mapping scheme, students who are fond of doing activities in the laboratory (research) can be directed to participate in competitions at the local and national levels through their research. Completion of final student assignments can be designed with publishable data. The laboratory is a supporting facility that will be used by students so that they automatically achieving the vision of laboratory development. Some examples of students who have a passion in our laboratory have been able to show their performance in producing publications in quality journals [11] [12].

Students who have talent and interest in traveling can be directed by the laboratory to carry out activities such as internships and research collaborations outside the area. For example, joint research students sent to several universities were able to produce quality data to be written in books and in other forms of scientific publications [13]. In essence, students 'final assignment activities need to be directed by the laboratory under the tendencies of students' interests and talents.

\subsection{Tropical functional food research theme}

The functional terms in food indicate an additional function of food besides fulfilling the nutrition needs. More importantly, functional food links health claim to the concept of food development. The first function, nutrition, may be defined as components that suffice physiological and biological elements that involve in the development and maintenance of the human body. The health benefit of food may be categorized as a risk reduction of a particular disease or support to increase the quality of life in a specific health condition. Functional food is often consumed as food and is in other forms than pharma products. Functional foods may be delivered in the form of fresh vegetables and fruits, roasted, snack bars, smoothies, jelly, jam, juice, bread, emulsion, fermented food, and others.

The functional food claim may also not as specific as pharma products, i.e., improved quality of life, risk prevention of disease, complementary reduction of a symptom caused by a disease, and helping metabolism pre-cursors. The label of functional food should not be introduced if the claim is not laboratory-verified or well understood, at least in the literature. 


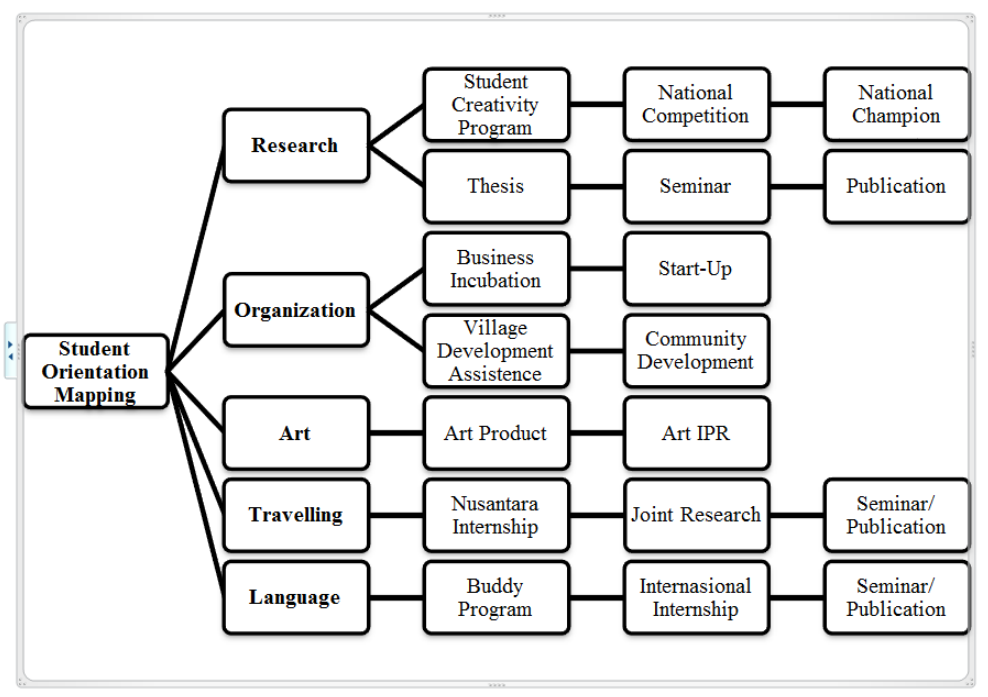

Fig. 2. Student orientation mapping

One function of a laboratory is to verify potential traditional knowledge. The first step to verifications is collecting and referencing rumor on a specific conventional functional food. Once verified, the potential functional food sources may undergo species confirmation, health claim hypothesis development, and literature study. Laboratory may then lead scientific findings of the respected functional foods, which includes the isolation of active compounds, characterization of formulated product, and verification of active mechanism of biological, cellular, or molecular action. The more advanced approach conducted in the laboratory may include acute and subchronic toxicity assessment. Clinical efficacy verification may be conducted in the last stages. The commercialization of functional food has several approaches, including formulation, certification, industrial licensing, and product release (see Figure 3).

This integrated approach may require multi-disciplinal research fields, hence requiring a laboratory to have a strong vision, active collaboration, and persistence effort to successfully release a functional food product [14]. Also, the time span of functional food development requires sustained generations of researchers and students. Bringing the result from the laboratory bench to classes may enhance the idea and also strengthen the motivation of the students and researchers on the functional food research theme. Hence, horizontal integration between functional food research to teaching excellence is a critical concept to produce a satisfactory result. 


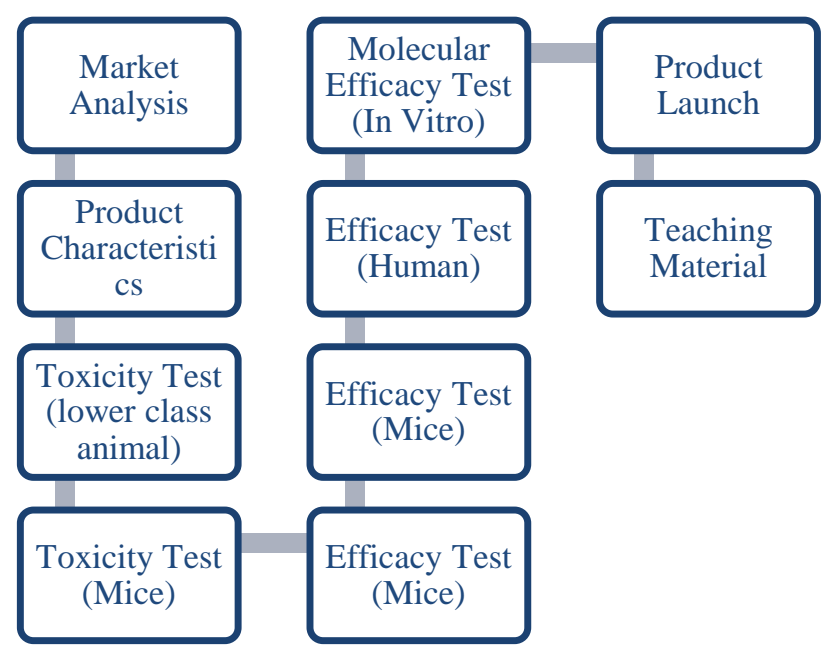

Fig. 3. The typical stages of product development in the functional food research theme

\subsection{Horizontal integration concept}

Balkos et al. [15] report a case study of horizontal integration between the active skills and teaching of engineering students. In our experience, this approach has been well-practiced since 2013. Results from research students were brought to the in-class discussion; hence the new students are well aware of the expectation they are requested in later stages of their education. Since not all laboratory is the same, the horizontal integration concept that we offer was implemented explicitly from near zero working facility in 2005 to semi-advanced capacity in 2019.

An excellent science education laboratory has a long term vision. Therefore they undergo a complicated process to advance and conquer the future challenge in research and education. The proposed framework of horizontal integration is depicted in Figure 4. Internalization of the vision is key to success in the science laboratory, as reported by Auer et al. [16]. Therefore, we put the vision internalization as the first stage in our horizontal integration framework. In the current field of specialization, there is a slogan called "only paranoid survive" [17]. The motto means that only the ones that show steady persistence that can achieve long term success. The persistence concept is the inspiration for the second stage of our horizontal integration framework. According to Christensen et al. [18], horizontal integration on food-specific research themes may require access to the internet (or new) technology, collaboration, coordination, information, and communication. In this case, we arrange new tech adaptation on the third step of the framework.

Collaboration is a sound stage after establishing a robust and productive baseline on laboratory research power. Collaboration may be in the form of physical attendance to external laboratory or inviting guest researchers to work in our laboratory. However, the advancement of communication technology and simulation enables the implementation of digital collaboration, i.e., through combined effort on simulated 
testing, open-access research methods and data, and open science concepts [19]. We put this collaboration concept in the fourth stage of our laboratory development framework. Laboratory activity without an outcome is meaningless. Therefore in each step of the idea, the outcome is measured and consequently integrated into the teaching class, producing a cutting edge teaching quality to the newer generation [20].

\begin{tabular}{|c|c|c|c|}
\hline $\begin{array}{c}\text { Stage I. } \\
\text { Vision } \\
\begin{array}{c}\text { Internaliza- } \\
\text { tion }\end{array}\end{array}$ & & $\begin{array}{c}\text { Stage III. } \\
\text { New Tech } \\
\text { Adaptation }\end{array}$ & $\begin{array}{c}\text { Stage V. } \\
\text { Outcome } \\
\text { Integration }\end{array}$ \\
\hline & $\begin{array}{c}\text { Stage II. } \\
\text { Persistence } \\
\text { Propagation }\end{array}$ & & \\
\hline
\end{tabular}

Fig. 4. The proposed framework of horizontal integration

\subsection{Vision integration}

The concept of vision integration starts from Laboratory, where researchers develop the research roadmap based on their expertise [21]. The functional food research umbrella is mostly approachable through product design. Extensive research, or more commonly recognized as umbrella research, is often an inter- and transdisciplinary approach [22]. For instance, functional food may be related to the biological nature of plants. Researchers in different epistemologies carried out species specimen identification and verification. This process is not familiar to any food technologist, but plant biologist. Plants (and animals) as sources of functional food can slightly differ on active compound content due to the sub-species, climate, soil, and harvesting maturity.

Transdisciplinary knowledge may also be related to biochemical pathways of active compound synthesis and functions in human or animal models. Researchers have to put consideration of pre-clinical trials, a method that is common to a clinical nutritionist or medical practitioner. The preparation of functional food to industrial-scale production requires an understanding of the physical and engineering properties of designated food material. Therefore, chemical engineering expertise should be taken into account. An excellent sensory preference or acceptability is in need to objectively measure the predicted perception of the end-consumer on a developed food formula. The successful functional food commercialization requires knowledge in human perception analysis. In said integration, learning opportunities are offered to research students in collaboration with other colleagues in respective fields [23].

The vision integration means the researcher in laboratory has an extensive research map and scenario while creating a milestone for each activity. To devise the intricate design, researchers often disburse the whole agenda to smaller operations, i.e., distribution of work to collaborators and research attendance (or students). 


\section{7 $\quad$ Persistence propagation}

The concept of persistence related success is nothing new, most famously stated by Thomas Alva Edison [24]. However, challenges in propagating persistence are described by a lack of research-ready facility and the nature of the student cycle. In most situations in Indonesia, the laboratory is inadequately equipped. There is only a handful of research-ready laboratory available in the country, while demands to compete in research productivity is seriously linked to the career of researchers [25]. Hence, the survivors in research often heavily invest in most needed equipment in the early stages. Therefore analysis can be carried out business as usual. We found that constant investment in laboratory equipment and newly acquired procedures are keys to long term productivity.

Researchers may require to bring new results and publications to classes, i.e., in the subject of Research Methodology. It gives ideas to junior students, sparking inspiration, and also laboratory excellence that should be consistently maintained. Concerning achieving a higher chance of success, students are expected to join research groups. Peer may assist in the actual bench workload, being typo and grammar hunter, or simply being a good listener that shares the same situation.

\subsection{New technology adaption}

Solving the current problem requires a better approach. Therefore new technology adaptation is always welcome [26]. In the past, the Internet of Things (IoT) and tinkering electronic sensors were never easy. In our lab, the use of IoT as a research tool began in 2013, when the essential equipment needed for a particular measurement was required, i.e., to measure the rate of water evaporated in functional raw material drying. Initially, the drying chamber was designed with a concept of enabling a twohybrid source of energy: sun and electric heater. Fans and on-off relay for the drier are temperature and humidity stabilizing contraptions. The first design focused on the position of fans and energy expenditure while reading humidity as an approach to calculate drying kinetics. This particular research is enabled by lending expertise from Computer Science Department. The second prototype addressed the overall design of the chamber, thus producing a more efficient drying process while reducing the energy requirement. The fundamental research produced two significant outputs: IoT knowledge acquisition in the form of a monograph [27].

Extensive material available on IoT, most significantly open hardware, userfriendly integrated development environment (IDE), and ready to use libraries, is the enabler of faster new technology absorption in non-electro laboratory. In particular, Arduino and Raspberry are the two most popular hardware-level programming being used in our laboratory. Regular application of IoT is taught in separated subjects of Physics (Introduction to Electronics chapter), Introduction to Computer or Programming in Food Engineering (General Knowledge of Data Acquisition chapter), and Thermobacteriology as a mean to measure pasteurization profile of various bottled foods. In summary, new technology adaptation empowers the laboratory to conduct 
specific research and is a teaching medium to understand better the phenomenon related to food properties.

\subsection{Extending collaboration}

A good collaboration starts with sharing small things that can be done together. For example, collaboration is built on the principle of resource sharing, which is the division of labor between laboratories carried out based on the competence of implementing human resources, instruments, and methods commonly used. Therefore, our laboratory was built with a focus on antioxidant tests for all possible methods done by spectrophotometric methods. If collaboration is needed for measurement based on Fourier Transformed Infra-Red (FTIR), then the work is delegated to laboratories that have competence in the field of chemo-metrics. Likewise, for liquid chromatographybased measurements, the work is carried out in other laboratories specialized for such matters. Thus, all laboratories involved in the collaboration will be able to sharpen their respective competencies.

Academic collaboration with this pattern is built on the principle of mutual benefit and mutual trust. Among the problems that were first solved in the memorandum of understanding on cooperation was the intellectual rights generated in the collaborative research [28] . Agreement on the distribution of resources and intellectual property rights need to be written down in the cooperation document, although in practice, it will take place more flexibly on the principle of mutual trust.

\subsection{Outcome integration}

The first scheme in the integration of research outputs with classroom teaching is to bring research results to the classroom [29]. Students not only learn from theories in textbooks but also actually gain actual research data exposure [30]. For example, the regular application of IoT is taught in separated subjects of Physics (Chapter of Introduction to Electronics), Introduction to Computer or Programming in Food Engineering (Chapter of General Knowledge of Data Acquisition), and Thermobacteriology as a mean to measure pasteurization profile of various bottled foods (see Figure 5).

The second scheme in output integration is to utilize students who have finished conducting research to conduct tutorials and skill transplantation to the next generation of students [31]. The advantage of this method is that the next generation of students directly learns workmanship strategies that may not be directly written in the publication. For example, it gives a real-word advice on the technique of stirring, adjusting, and diluting the sample against a standard curve, the homogeneity of the data distribution, the data processing technique, and how to suspect data exclusions. 


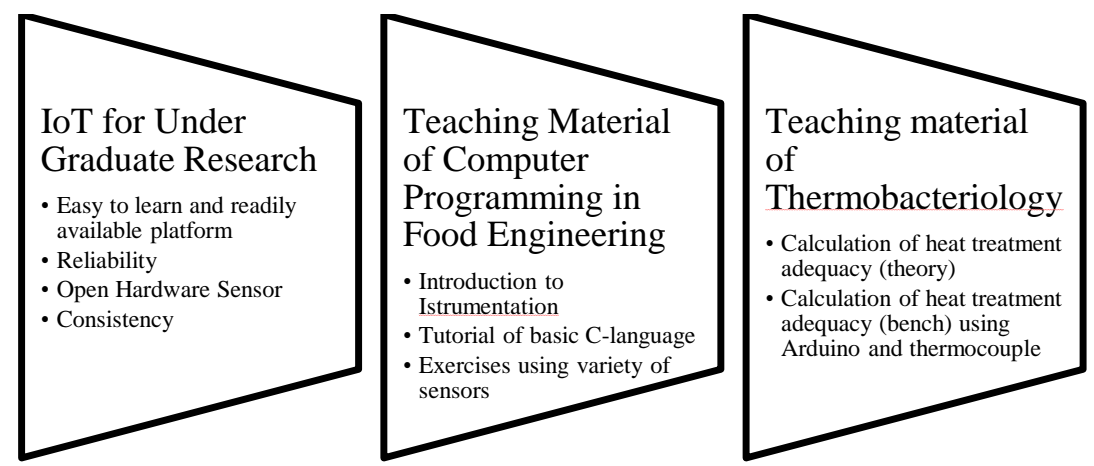

Fig. 5. Example of imparting knowledge discovery in the laboratory to teaching material

\subsection{The framework implementation impact}

The implementation of the vision internalization stage results in a better understanding of the big picture and how to solve problems systematically [32]. The most visible impact in the implementation of this stage is to empower the laboratory and to expose the student to the real-world situation of designing good research. Persistency in propagating the excellence of the laboratory will strengthen concept development and idea execution to provide consistent outputs in a long term scenario. The agility to adopt new technology helps the laboratory to refresh the competitiveness, and therefore, is vital to the survival of the laboratory. Research power is further extended by a good collaboration network. It enables access to other laboratories and strengthening the research capacity. Finally, outcome integration has an impact on translating research power in teaching excellence.

Table 4. Summary of the framework impact

\begin{tabular}{|l|l|}
\hline Framework Stage & \multicolumn{1}{c|}{ Impact } \\
\hline $\begin{array}{l}\text { Vision } \\
\text { Internalization }\end{array}$ & Empowering laboratory to provide substantial research power \\
\hline $\begin{array}{l}\text { Persistence } \\
\text { Propagation }\end{array}$ & $\begin{array}{l}\text { Concept development and Idea execution to provide consistent output, i.e., an } \\
\text { increasing number of publication, partnerships, and maintaining the flow of student }\end{array}$ \\
\hline $\begin{array}{l}\text { New Technology } \\
\text { Adaptation }\end{array}$ & $\begin{array}{l}\text { Refreshes laboratory with new method acquisition to offer a modern edge of novelty } \\
\text { to keep on the competition with other laboratories }\end{array}$ \\
\hline $\begin{array}{l}\text { Extending } \\
\text { Collaboration }\end{array}$ & $\begin{array}{l}\text { To provide access to other laboratory and environment in providing a larger } \\
\text { academic carrying capacity }\end{array}$ \\
\hline Outcome integration & $\begin{array}{l}\text { To provide a better teaching quality and to refresh knowledge taught in the class, to } \\
\text { upgrade the qualification of students with newly adapted skills }\end{array}$ \\
\hline
\end{tabular}

\section{$4 \quad$ Summary}

A five-stage framework is established to build a competent laboratory, from zero to certain success. This research power is achieved as a result of the careful capacity building considering the student background and facility challenges in our scenario at 
the University of Mulawarman. The five-stage framework includes vision internalization, persistence propagation, new technology adaptation, extending collaboration, and outcome integration. The framework states to empower the laboratory to provide substantial research power. Researchers may visit and align the current curriculum in the subject of Functional Food Technology. In the end, the framework provides teaching excellence hence strengthening the graduate competences - the horizontal integration with emphasize on IoT results in a unique set of research-teaching excellence framework that is incrementally developed.

\section{Acknowledgement}

The author would like to thank the Ministry of Research and Technology, the Ministry of Education and Culture, and the University of Mulawarman. The author would like to thank Malang State University for providing the opportunity and space to write the experience.

\section{References}

[1] Quigley, C. F., Herro, D., \& Jamil, F. M. (2017). Developing a conceptual model of STEAM teaching practices. School Science and Mathematics, 117(1-2), 1-12. https://doi. org/10.1111/ssm.12201

[2] Horvath, J. C., Lodge, J. M., \& Hattie, J. (Eds.). (2016). From the laboratory to the classroom: Translating the science of learning for teachers. Routledge.

[3] Tu, Y. (2016). Artemisinin - a gift from traditional Chinese medicine to the world (Nobel lecture).Angewandte Chemie International Edition, 55(35), 10210-10226. https://doi.org/ $\underline{10.1002 / a n i e .201601967}$

[4] McNamara, D. S., \& Kendeou, P. (2017). Translating advances in reading comprehension research to educational practice.International Electronic Journal of Elementary Education, 4(1), 33-46.

[5] Rahmadi, A., Istiqamah, I., Adriyanto, M. 2010. Education in Remote Areas from Teacher's Perspectives: a case study of East Kalimantan, INDONESIA. Di dalam: Zulfa Sakhiyya, I Made Andi Arsana, Mikha Rahmadewi (eds). Education Counts! Perhimpunan Pelajar Indonesia Australia. [accessed from: https://www.researchgate.net/publication/ 235935900_Education_in_Remote_Areas_from_Teacher's_Perspectives_a_case_study_of _East_Kalimantan_Indonesia] https://doi.org/10.1596/33113

[6] Rahmadi, A. 2018. Mengasah Berlian Kalimantan: Sebuah Upaya Transformasi Mahasiswa asal Pedalaman Kalimantan untuk Siap Menjawab Tantangan di Era Disruptif. A chapter in a Book Series of Learning Innovation. Universitas Negeri Malang, Malang, Indonesia, book in press.

[7] Herrmann, N. (1996). The Brain Business Book. USA: McGraw-Hill.

[8] Penprase, B. (2016). Intercultural Dialog Faculty Workshops at Yale-NUS. [accessed from: http://bryanpenprase.org/uncategorized/intercultural-dialog-workshops-at-yale-nus/]

[9] Yu, Y., Wang, F., \& Wang, T. (2019, October). A Study on the Relationships between Adolescent Inferiority and Grit. In 4th International Conference on Modern Management, Education Technology, and Social Science (MMETSS 2019). Atlantis Press. https://doi.org/10.2991/mmetss-19.2019.54 
[10] Gagné, F. (2018). Academic talent development: Theory and best practices. In S. I. Pfeiffer, E. Shaunessy-Dedrick, \& M. Foley-Nicpon (Eds.), APA handbooks in psychology®. APA handbook of giftedness and talent (p. 163-183). American Psychological Association.https://doi.org/10.1037/0000038-011https://doi.org/10.1037/ $\underline{0000038-000}$

[11] Bohari B, Muhadir M, and Rahmadi A. (2018). Vacuum evaporation and nitrogen-assisted deodorization affect the antioxidant capacity in the olein fraction of red palm oil and its emulsion products.F1000Research 2018, 7:1729. https://doi.org/10.12688/f1000research.1 $\underline{6545.1}$

[12] Rahmadi A, Sabarina Y and Agustin S. (2018). Different drying temperatures modulate chemical and antioxidant properties of mandai cempedak (Artocarpus integer). F1000Research2018, 7:1706. https://doi.org/10.12688/f1000research.16617.1

[13] Rahmadi, A., Sari, K., Handayani, F., Yuliani, Y., \& Prabowo, S. (2019). Modulation of Phenolics Substances and Antioxidant Activity in Mandai Cempedak By Unsalted Spontaneous and Lactobacillus casei Induced Fermentation. Jurnal Teknologi dan Industri Pangan, 30(1), 75-82. https://doi.org/10.6066/jtip.2019.30.1.75

[14] Granato, D., Nunes, D. S., \& Barba, F. J. (2017). An integrated strategy between food chemistry, biology, nutrition, pharmacology, and statistics in the development of functional foods: A proposal. Trends in Food Science \& Technology, 62, 13-22. https:// doi.org/10.1016/j.tifs.2016.12.010

[15] Balkos, M. K. D., Dow, B., Shams, S., Al-Hammoud, R., Emelko, M. B., Walbridge, S., \& Bachmann, C. (2017, June). Pedagogical Skill Development Through the Horizontal Integration of a Second-Year Engineering Curriculum. InProc. ASEE 124th Annual Conference and Exposition (Columbus, OH). https://doi.org/10.18260/1-2--28734

[16] Auer, M. E., Azad, A. K., Edwards, A., \& De Jong, T. (Eds.). (2018). Cyber-physical laboratories in engineering and science education. New York: Springer.

[17] Canty Jr, J. (2017). Leaders in Cardiovascular Science. Circ Res, 120, 1862-1864.

[18] Christensen, F. M., Mantravadi, S., Dukovska-Popovska, I., Hvolby, H. H., Steger-Jensen, K., \& Møller, C. (2019, September). Horizontal Integration in Fresh Food Supply Chain. InIFIP International Conference on Advances in Production Management Systems (pp. 164-172). Springer, Cham. https://doi.org/10.1007/978-3-030-30000-5_22

[19] Bärtle, R., Domian, A., Nutzmann, M., \& Sauer, T. (2019). Design Study of a Collaboration Laboratory for Product Design and Development. InDS 95: Proceedings of the 21st International Conference on Engineering and Product Design Education (E\&PDE 2019), University of Strathclyde, Glasgow. 12th-13th September 2019. https://doi.org/10.3 $\underline{5199 / \text { epde2019 }}$

[20] Ryan, B. J. (2019). 4 Integration of technology in the chemistry classroom and laboratory. Teaching Chemistry in Higher Education: A Festschrift in Honour of Professor Tina Overton, 39.

[21] Zidoun, Y., Dehbi, R., Talea, M., \& Arroum, F.-Z. E. (2019). Designing a Theoretical Integration Framework for Mobile Learning. International Journal of Interactive Mobile Technologies (IJIM), 13(12), 152-170. https://doi.org/10.3991/ijim.v13i12.10841

[22] Fortuin, K. P. J., \& Van Koppen, C. S. A. (2016). Teaching and learning reflexive skills in inter-and transdisciplinary research: A framework and its application in environmental science education. Environmental Education Research, 22(5), 697-716. https://doi.org/10. $1080 / 13504622.2015 .1054264$

[23] Gillis, D., Nelson, J., Driscoll, B., Hodgins, K., Fraser, E., \& Jacobs, S. (2017). Interdisciplinary and transdisciplinary research and education in Canada: a review and suggested 
framework. Collected Essays on Learning and Teaching, 10, 203-222. https:// doi.org/10.22329/celt.v10i0.4745

[24] Clark, R. (2012). Edison: The man who made the future. A\&C Black.

[25] Chusni, M. M., Hasanah, A., Ghazali, A. M., Zakwandi, R., \& Malik, A. (2019, October). The effect of laboratory processing capability and science literacy of readiness become professional pre-service physics teachers. In Journal of Physics: Conference Series (Vol. 1318, No. 1, p. 012083). IOP Publishing. https://doi.org/10.1088/1742-6596/1318/1/0120 $\underline{83}$

[26] Calori, I. C., \& Divitini, M. (2009). Reflections on the Role of Technology in City-wide Collaborative Learning. International Journal of Interactive Mobile Technologies (IJIM), 3(2), 33-39. https://doi.org/10.3991/ijim.v3i2.746

[27] Rahmadi, A., Agus, F., Murdianto, W., Setiawan, H., Santoso, A., Octalina, R. (2016). Desain Alat Pengering Berbasis Arduino. Mulawarman University Press.

[28] Müller, R. (2012). Collaborating in life science research groups: The question of authorship. Higher Education Policy, 25(3), 289-311. https://doi.org/10.1057/hep.2012.11

[29] Eteokleous, N., \& Ktoridou, D. (2009). Investigating Mobile Devices Integration in Higher Education in Cyprus: Faculty Perspectives. International Journal of Interactive Mobile Technologies (IJIM), 3(1), 38-48. https://doi.org/10.3991/ijim.v3i1.762

[30] Brownell, S. E., Kloser, M. J., Fukami, T., \& Shavelson, R. (2012). Undergraduate Biology Lab Courses: Comparing the Impact of Traditionally Based" Cookbook" and Authentic Research-Based Courses on Student Lab Experiences. Journal of College Science Teaching, 41(4).

[31] Ding, N., \& Harskamp, E. G. (2011). Collaboration and peer tutoring in chemistry laboratory education. International Journal of Science Education, 33(6), 839-863. https:// doi.org/10.1080/09500693.2010.498842

[32] May, D., \& Ossenberg, P. (2015). Organizing, performing and presenting scientific work in engineering education with the help of mobile devices. International Journal of Interactive Mobile Technologies (IJIM), 9(4), 56-63. https://doi.org/10.3991/ijim.v9i4.47 $\underline{26}$

\section{$7 \quad$ Authors}

Anton Rahmadi works for University of Mulawarman in Samarinda of Indonesia.

Miftakhur Rohmah and Uni Wahyuni Sagena work for University of Mulawarman in Samarinda of Indonesia. Emails: mithanavara@gmail.com, unisku@unmul. $\underline{\text { ac.id }}$

Article submitted 2020-03-27. Resubmitted 2020-05-15. Final acceptance 2020-05-17. Final version published as submitted by the authors. 